\title{
PENGARUH PENDEKATAN PELATIHAN BERBASIS KOMPETENSI TERHADAP KEMAMPUAN PRAKTEK MAKING BED DALAM PEMBELAJARAN ROOM SECTION DI SMK AKOMODASI PERHOTELAN
}

\author{
Popy Kusdamayanti ${ }^{1)}$, Tati Abas ${ }^{2)}$, Yoyoh Jubaedah ${ }^{3)}$ \\ ${ }^{1,2,3)}$ Program Studi Pendidikan Kesejahteraan Keluarga \\ FPTK, Universitas Pendidikan Indonesia
}

\begin{abstract}
Abstrak
Masalah penelitian ini dilatarbelakangi oleh kondisi kesenjangan antara kompetensi SMK dengan kompetensi SKKNI (Standar Kompetensi Kerja Nasional Indonesia), sementara SKKNI sudah menegaskan bahwa SMK untuk menyesuaikan dengan standar kompetensi dunia kerja. Program CBT (Competency Based Training) adalah salah satu pendekatan agar peserta didik lebih mudah menguasai kompetensi yang dibutuhkan dunia kerja. Penelitian ini bertujuan untuk mengetahui besarnya pengaruh pendekatan pelatihan berbasis kompetensi terhadap kemampuan praktek making bed dalam pembelajaran room section di SMK akomodasi perhotelan. Penelitian ini menggunakan metode deskriptif analitik. Sampel yang digunakan sampel purvosive sebanyak 35 peserta didik. Hasil penelitian tentang gambaran pengaruh pendekatan pelatihan berbasis kompetensi terhadap kemampuan praktek making bed berada pada kategori tinggi. Hasil pendekatan pelatihan berbasis kompetensi memberikan pengaruh positif terhadap kemampuan praktek making bed dalam pembelajaran room section di SMK akomodasi perhotelan.
\end{abstract}

Kata kunci: Pendekatan Pelatihan Berbasis Kompetensi, Praktek Making Bed, Pembelajaran Room Section.

\section{EFFECT OF COMPETENCE BASED APPROACH TO TRAINING APPROACH TO MAKING BED PRACTICAL COMPETENCY IN ROOM SECTION LEARNING AT VOCATIONAL SCHOOLS MAJOR IN HOSPITALITY ACCOMMODATION}

\begin{abstract}
This research issues motivated by the condition of the gap between vocational competence with competence SKKNI (Indonesian National Competence), while SKKNI already confirmed that the high schoo vocational competence for vocational schools adjust to the world of work competency standards. Programs CBT (Competency Based Training) is one approach that learners more easily master the competencies required work force. This study aims to determine the influence of competency based training approach to the practice of making beds in the ability of the learning room section at the vocational high school hospitality accommodation. This study used a descriptive a nalytic method. Samples used purvosive sample as many as 35 students. The results of the study illustrates the effect of a competency based training approach to making bed practical skills in the high category. The results of competency based training approach had a positive effecton the ability of the practice of making beds in a room learning in vocational high school accommodation section hospitality.
\end{abstract}

Keywords: Competency Based Training Approach, Practice Making Bed, Learning Room Section.

\section{PENDAHULUAN}

Penelitian ini beranjak dari penelitian payung yang berjudul Model Link And Match Dengan Pendekatan Competency Based Training Pada Pembelajaran Tata Graha Di Sekolah Menengah Kejuruan (Jubaedah, dkk., 2012), yang dilatarbelakangi oleh tuntutan terhadap Sekolah Menengah Kejuruan (SMK) memiliki peran dalam menyiapkan peserta didik yang mampu memasuki dunia kerja dan mengembangkan sikap profesional di bidang kejuruan. Peserta didik akan siap apabila mereka diberikan pengalaman belajar yang sesuai dengan tuntutan dunia kerja, sehingga akan mengurangi kesenjangan antara dunia 
pendidikan dengan dunia kerja. Penelitian ini bertujuan mengembangkan pengalaman belajar peserta didik melalui pendekatan pelatihan berbasis kompetensi dalam pembelajaran room section. Kompetensi di SMK belum selaras dengan kompetensi dunia kerja, sehingga tidak sedikit lulusannya sulit diterima di dunia kerja karena kurang menguasai kompetensi yang menjadi tuntutan dunia kerja. Fenomena ini menunjukkan bahwa SMK sebagai satuan pendidikan belum optimal dalam menyiapkan peserta didik dan lulusannya untuk menguasai tugas-tugas pekerjaan yang kompeten sesuai tuntutan dunia kerja. SMK perlu meningkatkan kompetensi yang selaras dengan tuntutan dunia kerja dengan menjalin kerja sama yang baik antara SMK dengan dunia kerja, sehingga lulusanya dapat direkomendasikan pada dunia kerja yang terkait kemitraan.

SMK perlu melakukan penataan program pembelajaran yang mengakomodasi tuntutan dari industri atau berbasis Standar Kompetensi Nasional. Dengan penataan yang sesuai dengan Standar Kompetensi Nasional, diharapkan SMK mampu meningkatkan kualitas pembelajaran yang selaras dengan kompetensi kerja sehingga akan berimplikasi pada kualitas lulusan SMK agar mengurangi pengangguran.

SMK memiliki peran untuk menyiapkan peserta didik agar siap bekerja, baik bekerja secara mandiri maupun mengisi lowongan pekerjaan pada dunia industri, seperti yang tersurat dalam UU No. 20 tahun 2003 SISDIKNAS BAB V Tentang Standar Kompetensi Lulusan. Pasal 26 yang menyebutkan bahwa: "Standar kompetensi lulusan pada satuan pendidikan menengah kejuruan bertujuan untuk meningkatkan kecerdasan, pengetahuan, kepribadian, akhlak mulia, serta keterampilan untuk hidup mandiri dan mengikuti pendidikan lanjut sesuai dengan kejuruan".

SMK Pekerja Sosial dan Pariwisata Negeri 15 Bandung memiliki 2 program keahlian yaitu: Program Keahlian Pekerja Sosial dan Program Keahlian Akomodasi Perhotelan. Struktur kurikulum SMK program keahlian akomodasi perhotelan mengacu pada Kurikulum SMK (2004) yaitu: "Untuk mencapai standar kompetensi yang telah ditetapkan oleh industry dan dunia usaha. Kompetensi yang diajarkan kepada peserta didik sesuai dengan standar kompetensi yang terbagi kedalam tiga program yaitu normatif, adaptif dan produktif".

Salah satu Mata Diklat Program Keahlian Akomodasi Perhotelan yang diberikan kepada peserta didik yaitu: kompetensi menyiapkan kamar tamu. Pengertian kompetensi menyiapkan kamar tamu berdasarkan kurikulum SMK (2004) yaitu: "Kemampuan yang merupakan perpaduan pengetahuan (knowledge), keterampilan (skill) dan sikap (attitude) peserta didik terhadap pembelajaran tentang menyiapkan, menata, membereskan, dan merapikan kamar dalam berbagai jenis kamar dan tempat tidur".

Pembelajaran Room Section yang dilaksanakan di SMK berorientasi pada dunia kerja, karena untuk menghasikan lulusan yang memiliki kompetensi kerja sesuai SKN dan relevan dengan dunia usaha dan dunia industri. Pembelajaran tersebut mengacu pada competency based training dalam pembelajaran kehlian produktif.

Pembelajaran room section yang diajarkan di SMK Negeri 15 Bandung terdiri dari teori dan praktikum. Pembelajaran room section meliputi: membersihkan dan merapihkan kamar tamu, salah satu yang menjadi masalah dalam penelitian ini adalah making bed. Making bed merupakan bagian dari room section yang membahas tentang membereskan tempat tidur tamu, baik yang masih dihuni oleh tamu maupun yang siap untuk dijual. Masalah yang ditemui penulis di SMK Negeri 15 Bandung khususnya bidang keahlian akomodasi perhotelan dalam pelaksanaan praktikum making bed masih menggunakan cara lama, yaitu dengan 3 sheet dan durasi 15-20 menit untuk individu, sementara dalam SKKNI sudah implisit bahwa intansi pendidikan kejuruan dihimbau untuk menyesuaikan dengan kompetensi di dunia kerja dengan cara lebih praktis dan efisien menggunakan Duvet dengan durasi 5-7 menit. Dengan demikian penulis melakukan penelitian melalui pendekatan pelatihan berbasis kompetensi terhadap kemampuan praktek making bed dalam pembelajaran room section di SMK akomodasi perhotelan. Dengan harapan setelah menerapkan pelatihan berbasis kompetensi peseta didik dapat lebih mudah memahami kompetensi yang diharapkan dunia kerja.

Bedasarkan uraian latar belakang di atas, maka perlu dilakukan penelitian mengenai pengaruh pendekatan pelatihan berbasis kompetensi terhadap kemampuan praktek making bed dalam pembelajaran room section di SMK akomodasi perhotelan. Permasalahan tersebut sangat berkaitan dengan ilmu yang penulis tekuni pada program studi PKK FPTK UPI khususnya pada konsentrasi tata graha 
(housekeeping), sebagai calon pendidik atau guru bidang akomodasi perhotelan.

Identifikasi dan Rumusan Masalah merupakan hal yang penting dalam penelitian. Tujuan dari identifikasi dan rumusan masalah penelitian ini supaya pembahasan dalam penelitian ini tidak terlalu luas, sehingga masalah yang diteliti menjadi jelas dan lebih terarah sesuai dengan fokus penelitian. Identifikasi masalah dalam penelitian ini adalah :

a. Adanya kesenjangan antara kompetensi di SMK dengan capaian kompetensi yang mampu menghasilkan lulusan sesuai tuntutan dunia kerja

b. Pelatihan berbasis kompetensi sebagai pendekatan pembelajaran dapat meningkatkan kemampuan praktek making bed dalam pembelajaran room section.

Rumusan masalah penelitian ini adalah: Bagaimana pengaruh pendekatan pelatihan berbasis kompetensi terhadap kemampuan praktek making bed dalam pembelajaran room section di SMK akomodasi perhotelan?

Tujuan dari penelitian ini adalah untuk memperoleh data yang berkaitan dengan:

a. Gambaran pelatihan berbasis kompetensi sebagai pendekatan dalam pembelajaran room section yang mengembangkan pengalaman pada peserta didik.

b. Gambaran kemampuan peserta didik dalam praktek making bed pada pembelajaran room section di SMK akomodasi perhotelan.

c. Pengaruh pendekatan pelatihan berbasis kompetensi terhadap kemampuan praktek making bed dalam pembelajaran room section.

d. Besarnya pengaruh pelatihan berbasis kompetensi terhadap kemampuan praktek making bed dalam pembelajaran room section.

\section{METODE PENELITIAN}

Penelitian ini mengunakan metode deskriptif analitik untuk memperoleh gambaran mengenai pengaruh pendekatan pelatihan berbasis kompetensi terhadap kemampuan praktek making bed dalam pembelajaran room section.

Lokasi penelitian yaitu SMK Negeri 15 Bidang Keahlian Akomodasi Perhotelan, beralamat di Jl. Gatot Subroto No. 04 Bandung. Populasinya adalah peserta didik kelas XI akomodasi perhotelan sebanyak 8 kelas yang berjumlah 270 peserta didik. Dari tiga kelas XI AP 1, XI AP 2, dan XI AP 3 yang menjadi model uji coba penelitian ini dipilih 1 kelas yaitu kelas XIAP 1 sebagai kelas uji coba, karena di kelas tersebut memiliki karakteristik yaitu: memilki pengalaman belajar yang lebih tinggi dibandingkan kelas lainnya, memiliki dkemampuan dalam menguasai tahapan praktek making bed yang sesuai SKKNI dan memiliki nilai yang lebih tinggi dari kelas lainya. Populasi dalam pembelajaran room section ini berjumlah 35 peserta didik.

Penelitian ini menggunakan sampel purvosive yang berarti teknik penentuan sampel penelitian ini melalui pertimbangan tertentu yang mempunyai ciri dan karakteristik sebanyak 1 kelas AP sebagai kelas uji coba model dengan jumlah 35 peserta didik.

\section{HASIL DAN PEMBAHASAN}

Berdasarkan hasil penelitian diketahui data pendekatan pelatihan berbasis kompetensi dengan skor maksimal 75 , skor minimal 12,67 dan skor rata-rata 37,5 .

Tabel 1 menunjukan pendekatan pelatihan berbasis kompetensi yang berkaitan dengan pengalaman belajar menggambarkan bahwa sebagian besar peserta didik (56,75\%) berada pada kriteria tinggi, kurang dari setengah peserta didik $(43,24 \%)$ berada pada kriteria cukup. Data tersebut dapat menunjukan dengan adanya pendekatan pelatihan berbasis kompetensi ditinjau dari pengalaman belajar peserta didik, lebih dari setengahnya berada pada kriteria tinggi.

Tabel 1. Data Hasil Pendekatan Pelatihan Berbasis Kompetensi

\begin{tabular}{|c|c|c|c|}
\hline Konversi & Kriteria & $\mathrm{f}$ & $\%$ \\
\hline $56 \leq$ & Sangat Tinggi & - & - \\
\hline $43 \leq \mathrm{X}<56$ & Tinggi & 24 & 56,75 \\
\hline $31 \leq \mathrm{X}<56$ & Cukup & 11 & 43,24 \\
\hline $18 \leq \mathrm{X}<31$ & Rendah & - & - \\
\hline $18>\quad$ Sangat Rendah & - & - \\
\hline \multicolumn{2}{|c|}{ Jumlah } & 35 & 100 \\
\hline
\end{tabular}

Data hasil pengukuran kemampuan praktik making bed dalam pembelajaran Room Section diperoleh skor maksimal 40, skor minimal 6,67 dan rata-rata skor 20. Secara lengkap kemampuan praktik making bed dalam pembelajaran Room Section ditunjukan dalam tabel di bawah ini (Tabel 2).

Hasil analisis data Tabel 2 pada peserta didik ditinjau dari kemampuan praktek making bed dalam pembelajaran room section yang meliputi kemampuan membersihkan dan merapihkan kamar tamu, dan mengganti linen 
yang kotor dengan linen yang baru sesuai dengan SKKNI, dapat digambarkan bahwa peserta didik telah mencapai kriteria tinggi $(94,3 \%)$. Data tersebut dapat menunjukan dengan adanya pendekatan pelatihan berbasis kompetensi ditinjau dari pengalaman belajar peserta didik sangat mempengaruhi pada kompetensi peserta didik ditinjau dari kemampuan praktek praktek making bed dalam pembelajaran room section.

\section{Tabel 2. Data Hasil Kemampuan Praktek Making Bed Dalam Pembelajaran Room Section}

\begin{tabular}{|c|c|c|c|}
\hline Konversi & Kriteria & $f$ & $\%$ \\
\hline $30 \leq$ & Sangat Tinggi & 1 & 2,7 \\
\hline $23 \leq X<30$ & Tinggi & 34 & 94,3 \\
\hline $16 \leq x<23$ & Cukup & - & - \\
\hline $9 \leq X<16$ & Rendah & - & - \\
\hline $0 \leq X<9$ & Sangat Rendah & - & - \\
\hline \multicolumn{2}{|c|}{ Jumlah } & 35 & 100 \\
\hline
\end{tabular}

Hasil perhitungan nilai koefisien determinasi (KD) diperoleh nilai koefisien determinasi sebesar $76,7 \%$. Perolehan tersebut artinya pengaruh pendekatan pelatihan berbasis kompetensi sebagai variabel (X) memberikan pengaruh $76,7 \%$ terhadap kemampuan praktek making bed dalam pembelajaran room section di SMK Akomodasi Perhotelan sebagai variabel (Y), adalah sebesar $76,7 \%$ berada pada kriteria tinggi, sedangkan sisanya sebesar 23,3\%. dipengaruhi faktor lain yang tidak diteliti oleh peneliti.

Pelatihan berbasis kompetensi merupakan kegiatan yang dilakukan dalam proses pengajaran benar-benar mengacu dan mengarahkan peserta didik untuk mencapai penguasaan kompetensi yang telah diprogramkan bersama-sama dengan dunia usaha dan dunia industri. Sejalan dengan pendapat Zurnali (2004), bahwa Kompetensi lulusan merupakan kualifikasi kemampuan lulusan yang mencakup sikap, pengetahuan, dan keterampilan sesuai dengan standar nasional yang telah disepakati.

Kondisi ini menunjukkan pengaruh yang kuat antara pendekatan Pelatihan Berbasis Kompetensi Terhadap Kemampuan Praktek Making Bed Dalam Pembelajaran Room Section Di SMK Akomodasi Perhotelan. Temuan ini menunjukan adanya nilai korelasi positif yang signifikan antara pendekatan pelatihan berbasis kompetensi terhadap kemampuan praktek making bed dalam pembelajaran room section di SMK Akomodasi Perhotelan.
Pembahasan hasil penelitian dikaji berdasarkan data empirik dan kajian literatur yang dideskripsikan sebagai berikut.

1. Gambaran Pendekatan Pelatihan berbasis kompetensi

Pelatihan berbasis kompetensi sebagai pendekatan pembelajaran yang menekankan peserta didik untuk mengembangkan pengetahuannya, ketrampilan serta sikap profesional di tempat kerja, sesuai dengan standar industri sebagai hasil dari training.

Data penelitian mengenai gambaran pelatihan berbasis kompetensi ditinjau dari pengalaman belajar dan kemampuan praktek making bed peserta didik menunjukan bahwa, lebih dari setengah peserta didik berada pada kriteria tinggi. Meskipun masih ada peserta didik yang menunjukan kurang menguasai kompetensi yang seharusnya sesuai dengan dunia kerja. Temuan hasil penelitian bedasarkan deskripsi data yang telah disajikan, dapat diketahui bahwa sebagaian besar peserta didik sudah kompeten sesuai SKNNI.

Temuan ini menegaskan bahwa, untuk menjadi individu yang memiliki kompetensi harus melalui pelatihan-pelatihan yang diterapkan di dunia kerja. Pelatihan yang diterapkan di intansi pendidikan maupun non pendidikan bertujuan untuk membekali ilmu kepada individu agar memiliki pengalaman yang cukup untuk menjadi lulusan yang kompeten. James (1970) memperkuat bahwa, pendekatan pelatihan berbasis kompetensi ini sebagai pedoman untuk menguasai kompetensi sebagai pelatihan yang bertujuan agar kurikulum pendidikan menyesuaikan dengan kurikulum dunia kerja.

\section{Gambaran Kemampuan Praktek Making Bed Dalam Pembelajaran Room Section}

Temuan penelitian mengenai gambaran kemampuan praktek making bed dalam pembelajaran room section bedasarkan data nilai praktek making bed dalam pembelajaran room section berada pada kriteria tinggi. Kondisi ini menunjukan bahwa peserta didik dapat melaksanakan praktek making bed dengan baik dan kompeten. Kondisi ini menunjukkan bahwa pendekatan pelatihan berbasis kompetensi pada praktek making bed memberikan pengaruh yang kuat terhadap kemampuan praktek making bed dalam pembelajaran room section. Peserta didik dapat melaksanakan praktek making bed di sekolah sesuai dengan yang diajarkan oleh guru yang mengacu pada kompetensi di dunia kerja. Sebagian besar peserta didik menguasai 
tahapan-tahapan praktek making bed. Namun, ada sebagian peserta didik pada saat praktek making bed yang belum menguasai kompetensi sesuai dengan kompetensi dunia kerja.

Hasil penelitian yang telah dilakukan sebagian besar peserta didik mampu menguasai kompetensi bagaimana pelaksanaan praktek making bed yang sesuai dengan kompetensi dunia kerja dari mulai persiapan diri yang mencakup: menyiapkan pakaian kerja, langkahlangkah making bed yang meliputi menyiapkan linen yang dibutuhkan praktek maing bed, pelaksanaan making bed, hingga produk atau hasil akhir dari pelaksanaan praktek making bed sebagai tolok ukur pencapaian kompetensi peserta didik sesuai atau belum dengan standar operasional prosedur. Peserta didik sebagai trainee mampu berkompeten dalam menyiapkan kamar tamu agar selalu siap untuk dijual. Sejalan dengan pendapat Agusnawar (2000) mengemukakan bahwa menjaga kebersihan dan kerapihan kamar tamu merupakan tanggung jawab petugas kamar (room section). Selain itu, peserta didik telah dianggap mampu untuk bersikap ramah, disiplin dan memberikan pelayanan yang prima dalam setiap tugasnya. Kompetensi tersebut ditunjukkan melalui datang tepat waktu sesuai jadwal praktek yang sudah ditentukan di sekolah dan melakasanakan tata tertib selama pelaksanaan praktek making bed.

3. Pengaruh pendekatan pelatihan berbasis kompetensi terhadap kemampuan praktek making bed dalam pembelajaran room section di SMK akomodasi perhotelan

Analisis pengaruh dalam penelitian ini meliputi hasil uji linearitas regresi, pengujian korelasi serta koefisien determinasi. Hasil penelitian tersebut diperoleh yaitu bila terjadi kenaikan satu variabel $X$, secara bersamaan diikuti oleh kenaikan variabel $Y$ sebesar 6,542 satuan, dengan kata lain jika skor rata-rata pendekatan pelatihan berbasis kompetensi meningkat satu satuan maka akan diikuti peningkatan keterampilan making bed sebesar 6,542 .

Bedasarkan hasil perhitungan analisis koefisien korelasi nilai korelasi menggunakan SPSS 20 diperoleh nilai $r=0,967$, sehingga diketahui nilai $r$ berada pada kategori tinggi. Analisis korelasi diperoleh variabel pendekatan pelatihan berbasis kompetensi dan kemampuan praktek making bed dalam pembelajaran room section nilai (sig) sebesar 0,000 kemudian dibandingkan dengan probabilitas $(0,05>0,000)$ ternyata nilai probabilitas 0,05 lebih besar dari nilai sig. Sebesar 0,000, maka hipotesis nol $\left(\mathrm{H}_{0}\right)$ ditolak dan hipotesis kerja $\mathrm{(Ha}$ ) diterima pada taraf kepercayaan $95 \%$ atau dengan kata lain terdapat pengaruh positif yang signifikan dari pendekatan pelatihan berbasis kompetensi (variabel X) terhadap kemampuan praktek making bed dalam pembelajaran room section (variabel Y).

4. Besarnya pengaruh pendekatan pelatihan berbasis kompetensi yang signifikan terhadap kemampuan praktek making bed dalam pembelajaran room section di SMK akomodasi perhotelan

Hasil pendekatan pelatihan berbasis kompetensi memberikan pengaruh yang tinggi terhadap kemampuan praktek making bed dalam pembelajaran room section di SMK akomodasi perhotelan. Bedasarkan hasil perhitungan koefisien determinasi sebesar = $76,7 \%$, perhitungan tersebut menunjukan bahwa hasil pendekatan pelatihan berbasis kompetensi terhadap kemampuan praktek making bed dalam pembelajaran room section sebesar $76,7 \%$ dan sisanya sebesar $23,3 \%$ dipengaruhi oleh faktor lain yang tidak diteliti dalam penelitian ini. Artinya, pendekatan pelatihan berbasis kompetensi memiliki pengaruh yang tinggi terhadap kemampuan praktek making bed dalam pembelajaran room section di SMK Akomodasi Perhotelan.

Faktor lain tersebut disebabkan karena setiap individu mempunyai kharakteristik yang berbeda-beda. Peserta didik yang melaksanakan praktek making bed dapat dikatakan kompeten atau tidak tergantung penilaian dari guru dan praktisi, dapat dilihat dari ketepatan waktu melaksanakan praktek making bed, disiplin selama melaksanakan praktek making bed, hingga penyelesaian praktek making bed. Artinya, peserta didik dapat memperoleh nilai tinggi setelah dilakukan pelatihan secara berkala, sehingga pelatihan yang semula sulit untuk dilaksanakan, menjadi lebih mudah dan praktis, karena proses pelatihan secara terstruktur berdasarkan modul pelatihan yang disediakan, sehingga sangat memungkinkan peserta didik belajar dan berlatih secara aktif dan mandiri. Pelatihan berbasis kompetensi atau competency based training berorientasi pada dunia kerja, di mana program dan materinya merupakan turunan dari SKKNI yang ditetapkan berdasarkan kesepakatan dengan pihak terkait dan disyahkan melalui Keputusan Menakertrans, yang diharapkan lulusan SMK dapat memenuhi kebutuhan dunia kerja. 
Pelatihan berbasis kompetensi merupakan kegiatan yang dilakukan dalam proses pengajaran benar-benar mengacu dan mengarahkan peserta didik untuk mencapai penguasaan kompetensi yang telah diprogramkan bersama-sama dengan dunia usaha dan dunia industri. Sejalan dengan pendapat Zurnali (2004), bahwa: Kompetensi lulusan merupakan kualifikasi kemampuan lulusan yang mencakup sikap, pengetahuan, dan keterampilan sesuai dengan standard nasional yang telah disepakati.

Kondisi ini menunjukkan pengaruh yang kuat antara pendekatan pelatihan berbasis kompetensi terhadap kemampuan praktek making bed dalam pembelajaran room section di SMK Akomodasi Perhotelan. Temuan ini menunjukan adanya nilai korelasi positif yang signifikan antara pendekatan pelatihan berbasis kompetensi terhadap kemampuan praktek making bed dalam pembelajaran room section di SMK akomodasi perhotelan.

\section{KESIMPULAN} berikut:

Kesimpulan hasil penelitian ini sebagai

1. Hasil penelitian mengenai gambaran pendekatan pelatihan berbasis kompetensi pada pembelajaran room section dilakukan pada peserta dididk SMKN 15 Bandung Program Keahlian Akomodasi Perhotelan menunjukan sebagian besar berada pada kriteria tinggi dalam peningkatan pengalaman belajar.

2. Hasil penelitian mengenai kemampuan praktek making bed dalam pembelajaran room section bedasarakan nilai praktek making bed yang diperoleh dari peserta didik sebagian besar peserta didik melaksanakan praktek making bed sesuai dengan standar operasional prosedur. Bedasarkan data nilai kemampuan praktek making bed menunjukan berada pada kriteria tinggi.
3. Hasil penelitian pendekatan pelatihan berbasis kompetensi yang diperoleh bedasarakan data pengalaman belajar peserta didik dan kemampuan praktek peserta didik keduanya menunjukan berada kriteria tinggi. Hal ini berarti menunjukan pengaruh yang kuat antara pendekatan pelatihan berbasis kompetensi terhadap kemampuan praktek making bed dalam pembelajaran room section.

4. Pendekatan pelatihan berbasis kompetensi memberikan pengaruh positif yang signifikan terhadap kemampuan praktek making bed dalam pembelajaran room section di SMK Akomodasi Perhotelan. Hasil penelitian ini menunjukan bahwa pendekatan pelatihan berbasis kompetensi memberikan pengaruh yang positif dan signifikan terhadap kemampuan praktek making bed di SMK Akomodasi Perhotelan.

\section{DAFTAR PUSTAKA}

Agusnawar. 2002. Operasional Tata Graha Hotel. Jakarta: Gramedia

Depdiknas. 2004. Kurikulum SMK 2004. Jakarta: Depdiknas

James,H. 1970. Mastery Learning. New York : Holt, Rinehart and Winston, Inc

Jubaedah, Y., dkk. 2012. Model Link and Match dengan Pendekatan Competency Based Training pada Pembelajaran Tata Graha di Sekolah Menengah Kejuruan. Laporan Penelitian Penguatan Kompetensi UPI Bandung : Tidak diterbitkan.

Undang-Undang No. 20 Tahun 2003 SISDIKNAS , Bab V, Pasal 26.

Zurnali, Cut. 2004. Pengaruh Pelatihan Dan Motivasi Teradap Perilaku Produktif Karyawan Pada Divisi Long Distance PT. Telkom Indonesia, Tbk. Tesis Program pasca sarjana Unpad, Bandung. 